\title{
Review on Recent Advances in Titanium Dye Oxide Nanoparticles for Dye Sensitized Solar Cell Applications
}

\author{
C. Divya ${ }^{1}$, B. Janarthanan ${ }^{2}$ J. Chandrasekaran ${ }^{3}$ \\ 1,2 Department of Physics, Karpagam University, Karpagam Academy of Higher Education Eachanari, India \\ ${ }^{3}$ Department of Physics, Sri Ramakrishna Mission Vidyalaya College of Arts and Science, Coimbatore, India
}

\begin{abstract}
Article Info
\section{Article history:}

Received Mar 14, 2017

Revised Apr 30, 2017

Accepted May 26, 2017

\section{Keyword:}

Characterization techniques Dye-sensitized solar cell Electrochemical anodization Hydrothermal method Natural dye Sol-gel method $\mathrm{TiO}_{2}$ nanoparticle

ABSTRACT

Alternate energy source becomes a crucial for green energy solution against ever increasing demand. Dye Sensitized solar cell is another promising option toward green energy providing opportunity to explore natural dye extracts from plants. This review explores recent developments in the field of Dye Sensitized solar cell technology specifically with sensitizer synthesized from plants which are also found in India. Anthocyanin, betalain, chlorophyll and carotenoids are among the most common plant pigments explored as sensitizers. The review of different attempts on fabrication of natural dye based solar cells implies that titanium dioxide (TiO2) nano particles can be used as photoanode, platinum $(\mathrm{Pt})$ as counter electrode and iodine/iodide electrolyte. Plant pigments are highly $\mathrm{pH}$ sensitive and can alter solar cell performance based on its extraction method, concentration and its ability to anchor with photoanode. Stability of dye, absorption in near IR range and leakage of liquid electrolyte are few of the challenges ahead. However, natural dye is biodegradable and non-toxic having most of the extraction process harmless to environment. In addition, natural dye has the promising future as it is abundant.
\end{abstract}

Copyright $@ 2017$ Institute of Advanced Engineering and Science. All rights reserved.

Corresponding Author:

C. Divya,

Department of Physics,

Karpagam University, Karpagam Academy of Higher Education Eachanari, India

Email: divyachan20@gmail.com

\section{INTRODUCTION}

Exhaustion of fossil fuels lead the world to shift from the conventional energy sources to renewable energy to meet the growing energy demand. Although the process is gradual but the potential of renewable energy was well talked in the past decade. Wind energy is effective, but due to the inconsistency of the blowing wind, it is not quite efficient. Unlike wind energy, solar energy has a fair amount of consistency. As a result, the conversion of solar energy into different forms was the core of the research for the recent past years [1].

Nanotechnology is a rapidly promising technology with vast potential in creating new materials with unique properties and to produce new and improved products for photo voltaic applications. The term nanoparticle refers to any small particle with all three dimensions less than 100 nanometres (nm) in size. It has a large surface area per unit mass. Titanium dioxide $\left(\mathrm{TiO}_{2}\right)$ nanomaterials are known for their numerous and different applications, which range from common products, such as sunscreens, to in advanced devices such as photovoltaic cells a series of environmental and biomedical applications such as photocatalytic degradation of pollutants, water purification, biosensing and drug delivery. The importance and variety of these applications have spur enormous interest and large advances in the fabrication, characterization, and fundamental understanding of $\mathrm{TiO}_{2}$ nanomaterials in the past decade[1-9]. Dye-sensitized Solar Cells (DSSCs) are promising devices for inexpensive, large-scale solar energy conversion. They are currently most efficient and stable excitonic photocells [10]. Central to this device is a thick $\mathrm{TiO}_{2}$ nanoparticle that provides a large surface area for the adsorption of light harvesting molecules. The best solar energy conversion 
efficiency achieved till date is $12.4 \%$ [11]. This article presents a review on the literature available on fabrication, characterisation, properties, applications and commercialization of DSSCs.

\section{DYE SENSITIZED SOLAR CELL}

\subsection{Basic Principle}

The basic operating principle for any TiO2 DSSC consists of absorption, separation and collection. These parameters are optimized in different types accordingly to attain better efficiency. Thus, absorption occurs at the first step of the reactions in DSSC. Under illumination, sensitizer dye (D) absorbs a photon which leads to excited sensitizer state $\left(D^{*}\right)$. Photoexcitation of this sensitizer is then followed by the electron injection into the conduction band of the semiconductor (mesoporous). This takes the sensitizer to an oxidized state $D^{+}$. With the electron donation from the electrolyte, containing a redox couple, the original state of the dye restored. Iodide/triiodide couple is the preferred and effective redox couple used. Iodide regenerates the sensitizer and it gets regenerated itself by the reduction of triiodide at the counter electrode. In this way the circuit gets completed by transferring electron via the external load. The following reactions summarize the work in a lucid manner: [12], [13]

$$
\begin{aligned}
& \mathrm{D}_{\text {(absorbed) }}+\mathrm{hv} \longrightarrow \mathrm{D}^{*}{ }_{\text {(absorbed) }}(1) \\
& \mathrm{D}^{*}{ }_{\text {(absorbed) }} \longrightarrow \mathrm{D}^{+}{ }_{\text {(absorbed) }}+\mathrm{e}^{-}{ }_{\text {(injected) }}(2)
\end{aligned}
$$

The construction of a Dye Sensitized Solar Cell can be categorized as follows: [13]

- A mechanical support coated with Transparent Conductive Oxides.

- The semiconductor film, usually $\mathrm{TiO}_{2}$

- A sensitizer absorbed onto the surface of the semiconductor

- An electrolyte containing a redox mediator

- A counter electrode is capable of regenerating the redox mediator

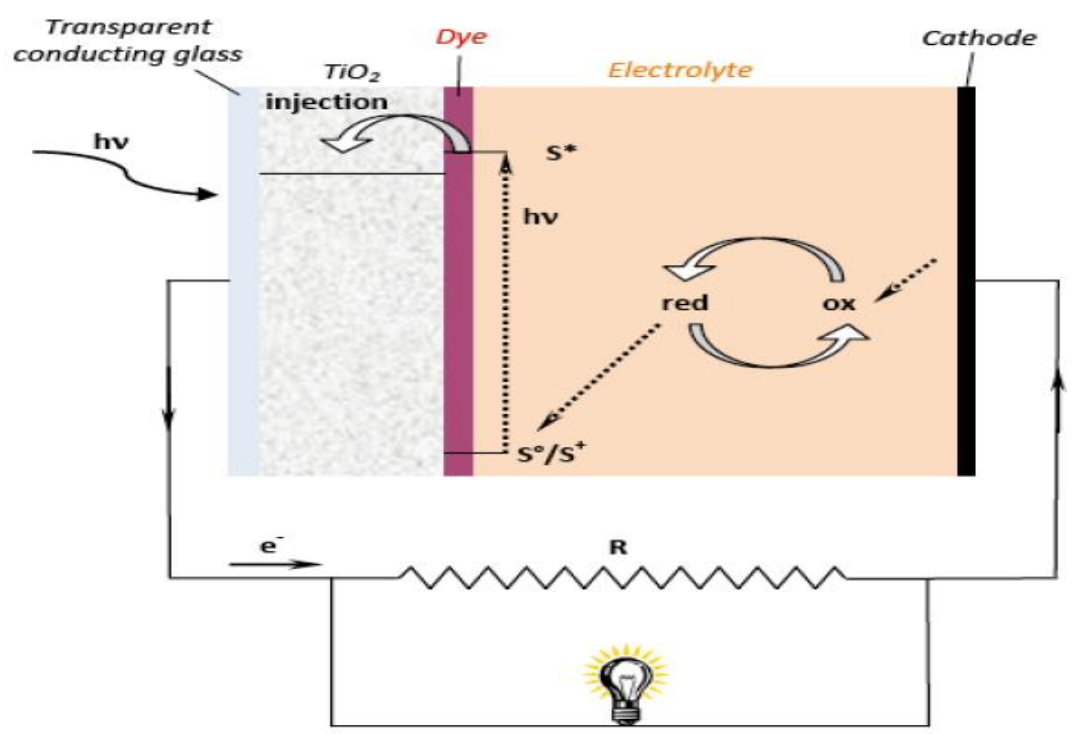

Figure 1. Schematic Principle of a DSSC: Photo Excitation of the Day (Sensitizer, S) Generates Electrons Which are Injected Into the Conduction Band of $\mathrm{TiO}_{2}$

In DSSCs, the function of light absorption and charge separation are isolated, unlike in the conventional silicon-based solar cells. Under light illumination, the interaction between the dye molecules and the photons cause their photo-excitation, thereby generating electron hole pairs. The electrons are injected into the conduction band of the semiconductor $\mathrm{TiO}_{2}$. This can occur on a fast or ultrafast time scale on the order of picoseconds or hundreds of Femto seconds. The oxidized state of the dye containing the holes is rapidly reduced by the electrolyte, thus regenerating the dye. This prevents back transfer of electrons. The electrons travel through the semiconductor to the transparent electrode and the external load and eventually reach the counter electrode and regenerate the electrolyte [14]. 


\subsection{Natural Dyes}

Coumarin dye, merocyanine dye and polyene dyes have been designed successfully as organic-dye photosensitizers in DSSCs, and high solar energy to electricity conversion efficiencies of up to $8 \%$ under AM 1.5 irradiation have been attained. The lower performance of DSSCs based on organic dyes compared to those based on Ru complexes is probably due to the lower open-circuit voltage (Voc) that is generated in the DSSCs based on organic dyes, rather than the performance of the short-circuit photocurrent density (Jsc), which is almost the same [17]. Natural sensitizers from plants are wide variety of flowers, leaves and fruits have been explored to extract natural sensitizer for solar cells, however scope of this review paper has been limited to sensitizers extracted from Indian plants in recent times. This study is also intended to identify Indian plants having potential to provide energy harvesting material.

Chromophores are responsible for the colour. Pigments can also be classified as natural, synthetic and inorganic based on its origin. Carotenoids provide yellow, orange and red colour to flowers and fruit. It absorbs visible light in the range of $470-550 \mathrm{~nm}$ usually not absorbed by chlorophyll. Carotenoids consist of eight isoprenoid units. They are classified as (i) Carotenes consisting carbon and hydrogen (ii) Oxycarotenoid or xanthophyll consisting carbon, hydrogen and oxygen. Primary Carotenoids are required for photosynthesis and secondary are found in fruits and flowers. Approximately carotenoid is produced 108 ton/year by nature [15]. Carotenoid molecules are very reactive and have quick degradation in presence of oxygen traces. Extraction of carotenoids is challenging as no optimal solvent is found which can completely avoid the degradation. Thin Layer Chromatography (TLC) can be used as one of the methods for separation being simple and economic. Absorption coefficient of carotenoids is 13 times higher than Ru based N-719 dye yet gives poor efficiency in DSSC due to poor dye regeneration [16].

Flavonoids can be grouped as anthocyanins, flavonols and proanthocyanidins. Anthocyanin has been widely explored as water soluble sensitizer rendering variety of colours from pink, red violet to dark blue. Its concentration varies from $0.1 \%$ to $1 \%$ dry weight in fruits and vegetables [17]. TLC is widely used to separate anthocyanin. Anthocyanin is most abundant and absorbs light at longest wavelength. Anthocyanin is affected by $\mathrm{pH}$, aggregation and temperature among other factors. Betalains are water soluble pigment with orange and red colour. Betalains have high color strength than anthocyanin and hence maintains its color on mixing with other dyes [18]. They are stable in the $\mathrm{pH}$ range of 3-7 (Strack et al., 2003). The most important characteristics is the presence of carboxyl functional group $(-\mathrm{COOH})$ that enables binding with $\mathrm{TiO}_{2}$ photoanode. Betalains are grouped as betacyanins having maximum absorptivity of $535 \mathrm{~nm}$ and betaxanthins of $480 \mathrm{~nm}$. Chlorophyll is the green colour pigment that is not stable in acid or base. They are abundant in nature and non-toxic. It has an advantage of tunable LUMO orbital by changing central metals for compatibility to conduction band of the photoanode [19].

Table 1.Dye Sensitized Solar Cell Based Different Sensitizers

\begin{tabular}{|c|c|c|c|c|c|c|c|c|}
\hline Dye & $\begin{array}{c}\text { Ano } \\
\text { de }\end{array}$ & $\begin{array}{l}\text { Absorption } \\
\text { peak (nm) }\end{array}$ & Electrolyte & $\begin{array}{l}\text { Counter } \\
\text { electrode }\end{array}$ & $\begin{array}{c}\mathbf{J}_{\mathrm{sc}} \\
\left(\mathrm{mA} \mathrm{cm}^{-2}\right)\end{array}$ & $\mathrm{V}_{\mathrm{oc}}(\mathrm{mV})$ & $\mathrm{FF}$ & $\eta(\%)$ \\
\hline Canna indical[20] & $\mathrm{TiO}_{2}$ & 513 & Iodide based & $\mathrm{Pt}$ & 0.82 & 540 & 59 & $0.29 \%$ \\
\hline Salvia splendens[20] & $\mathrm{TiO}_{2}$ & 507 & Iodide based & $\mathrm{Pt}$ & 0.7 & 558 & 61 & $0.26 \%$ \\
\hline Cowberry $[20]$ & $\mathrm{TiO}_{2}$ & 522 & $\begin{array}{l}\text { Iodide based } \\
\text { Phthaloyl }\end{array}$ & $\mathrm{Pt}$ & 0.4 & 539 & 54 & $0.31 \%$ \\
\hline Red cabbage[20] & $\mathrm{TiO}_{2}$ & 550 & $\begin{array}{c}\text { Chitosan: } \\
\text { PEO } \\
\text { NH4I+BMII }\end{array}$ & $\mathrm{Pt}$ & 3.509 & 340 & 39 & $0.46 \%$ \\
\hline Blackberry[20] & $\mathrm{TiO}_{2}$ & 538.25 & Iodide based & $\mathrm{Pt}$ & 2.7 & 297 & 38 & $0.245 \%$ \\
\hline Rose[21] & $\mathrm{TiO}_{2}$ & 600 & Iodide based & $\mathrm{Pt}$ & 0.97 & 350 & 66.6 & $0.38 \%$ \\
\hline $\begin{array}{c}\text { Pomegranate leaves } \\
{[21]}\end{array}$ & $\mathrm{TiO}_{2}$ & 665 & Iodide based & $\mathrm{Pt}$ & 2.09 & 560 & 52 & $0.597 \%$ \\
\hline Mallow[21] & $\mathrm{TiO}_{2}$ & 513 & Iodide based & $\mathrm{Pt}$ & 0.69 & 600 & 55 & $0.215 \%$ \\
\hline Annatto [21] & $\mathrm{TiO}_{2}$ & 570 & Iodide based & $\mathrm{Pt}$ & 1.1 & 590 & 59 & $0.37 \%$ \\
\hline Tamarind[21] & $\mathrm{TiO}_{2}$ & 410 & Iodide based & $\mathrm{Pt}$ & 0.18 & 610 & 56 & $0.48 \%$ \\
\hline Banana[21] & $\mathrm{TiO}_{2}$ & $400-550$ & Iodide based & $\mathrm{Pt}$ & 0.78 & 300 & 45 & $0.21 \%$ \\
\hline Pumpkin[22] & $\mathrm{TiO}_{2}$ & $400-550$ & Iodide based & $\mathrm{Pt}$ & 0.02 & 300 & 50 & $0.006 \%$ \\
\hline Henna[22] & $\mathrm{TiO}_{2}$ & $400-550$ & Iodide based & $\mathrm{Pt}$ & 0.199 & 503 & 0.476 & $0.052 \%$ \\
\hline $\begin{array}{l}\text { Musa[22] acuminata } \\
\text { (Banana flower) }\end{array}$ & $\mathrm{TiO}_{2}$ & $400-550$ & Iodide based & $\mathrm{Pt}$ & 0.485 & 556 & 0.557 & $0.168 \%$ \\
\hline Cherry[22] & $\mathrm{TiO}_{2}$ & 543 & Iodide based & $\mathrm{Pt}$ & 1.89 & 555 & 49 & $0.49 \%$ \\
\hline Black Grapes[22] & $\mathrm{TiO}_{2}$ & 520 & CuSCN & $\mathrm{Pt}$ & 1.19 & 449 & 50 & $0.59 \%$ \\
\hline
\end{tabular}




\subsection{Preparation of $\mathrm{TiO}_{2} \mathrm{DSSC}$}

The process of construction of solar cells begins with two glass plates coated with indium tin oxide (ITO). Glass in itself is non-conductive and hence the thin semiconducting layer of ITO allows charge to flow. The plates are first tested to find the conductive side of the glass. This conductive side is then covered with the other required materials. A uniform coating of titanium dioxide is applied to the conductive side of one plate using a glass rod. The $\mathrm{TiO}_{2}$ matrix is approximately $10-30 \mathrm{~nm}$ in diameter enabling a greater surface area for adsorption [23].

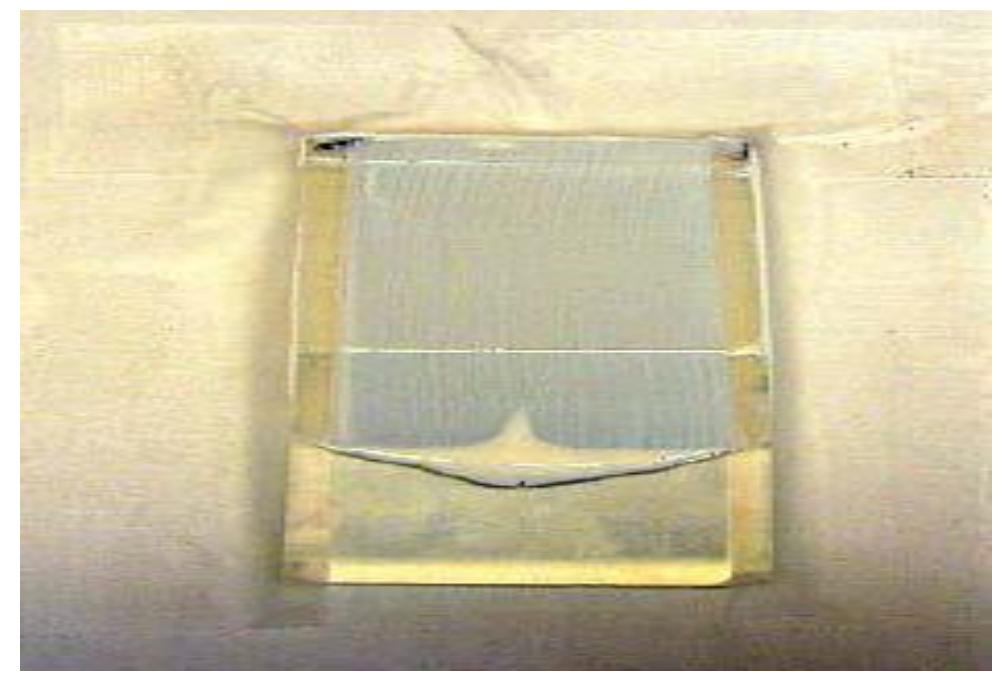

Figure 2. ITO Glass with $\mathrm{TiO}_{2}$ Substrate

The plate is then placed above a Bunsen burner for about $10-15$ minutes to allow $\mathrm{TiO}_{2}$ bind to the plate. This process called sintering which allows a three dimensional networks of about 10 to 30 nanometres thick to be achieved and thus favour electron flow. Following the sintering process, the plate is allowed to cool and is then placed in a bath of a dye solution (Ru535 bis-TBA, a Ruthenium-based pink dye which peaks at 384 and $530 \mathrm{~nm}$ in the UV-Visible spectrum, for example) for 30 minutes[24].

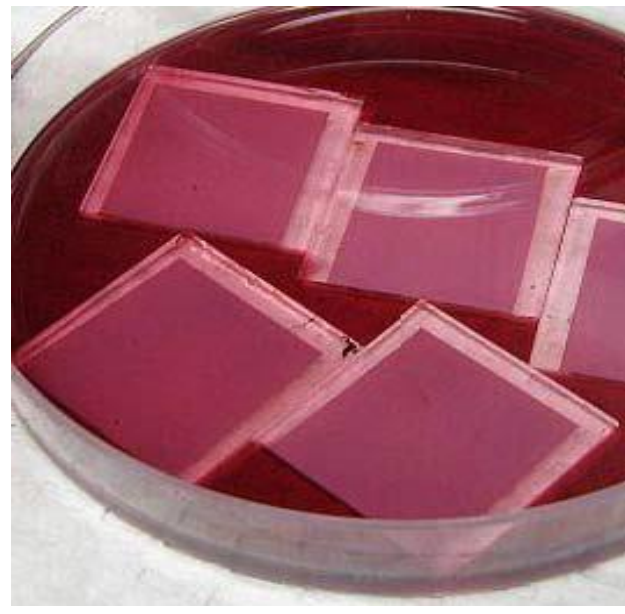

(a)

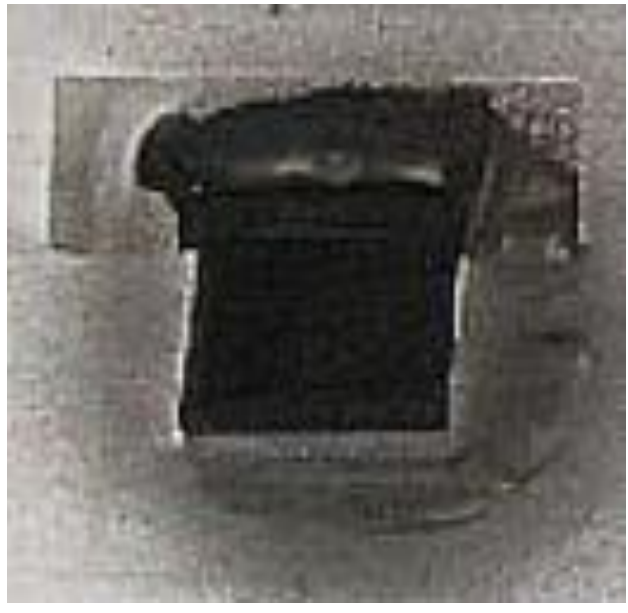

(b)

Figure 3. a) $\mathrm{TiO}_{2}$-coated Cells are Soaked in Dye Solution (Ruthenium-535) b) Cells After Spraying of Carbon as Counter Electrode 
The increased surface area of $\mathrm{TiO}_{2}$, nanoparticles permits a greater amount of dye molecules to be absorbed, which in turn translates into an increased flow of electricity. The amounts of electrons allowed to flow through the system are dependent upon the number of dye molecules present in the cells themselves. After absorption of the dye, the plate is placed under a heat gun for drying and then sprayed with an even coating of the counter electrode (carbon or platinum). Finally, it is again dried using a heat gun (reaching approximately $120^{\circ} \mathrm{C}$ ). This process may be repeated until the total number of desired cells is obtained. The individual pieces of glass are sandwiched together (conductive sides touching) and secured with binder clips [25].

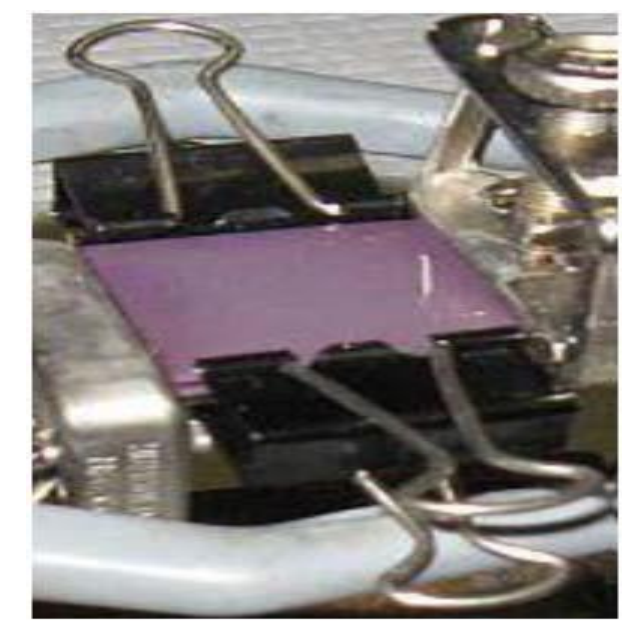

Figure 4. Dye-sensitised $\mathrm{TiO}_{2}$ Coated Solar Cells

\subsection{Preparation of TiO2 Nanoparticles}

Physical quantities including high ion exchange capability, high surface area due to their open mesoporous nature, proton conductivity and relative stability [25]. $\mathrm{TiO}_{2}$ nanoparticles having high efficiency, low cost, non toxic, environmental friendly, corrosion resistance material. It is frequently used in paint, white pigments, and sun-blockers. The key factors are exceptional biocompatibility and even more unique ionic and electronic propereties if this oxide.They have wide band gap semiconductor with suitable band gap positions that enable be to used in solar cells and photo cataliytic reactions [26]. $\mathrm{TiO}_{2}$ nanoparticles photocatalyst requirement of large amount of catalysts, difficulty in cata-lyst recycling and problematic agglomeration of $\mathrm{TiO}_{2}$ nano crystals into large particles [27]. Although immobilized $\mathrm{TiO}_{2}$ is the overall photocatalytic activity has been compromised due to the reduction of surface area and limitation in mass transfer [28]. In order to enhance photocatalytic activity and facilitate catalyst separation after photocatalytic reaction, onedimensional (1D) nanostructured materials such as nanotubes, nanowires and nanorods have been investigated. Besides, charge recombination probability within $\mathrm{TiO}_{2}$ nanoparticles also increases due to the presence of defects, surface states and grain boundaries which act as electron trapping sites [29].

\section{SYNTHESIS OF $\mathrm{TiO}_{2}$ NANOTUBES}

\subsection{Solgel Method}

The sol-gel is an important template assisted technique used for the synthesis of $\mathrm{TiO}_{2}$ anatase phase. In sol-gel process, a colloidal suspension or a sol is formed from the hydrolysis and polymerization reaction. Ching-Hsun et al. explained that $\mathrm{ZnO}$ nanoparticle seed solution was spin coated onto $\mathrm{TiO}_{2}$ by glass substrate, then that substrate immersed in Zinc Nitrate and methenamine aqueous solution at $80^{\circ} \mathrm{C}$ for $24 \mathrm{hrs}$ to grown $\mathrm{TiO}_{2}$ nanorods [30]. Dye extraction is an important activity in sol-gel process. Betanin is used by S.Ananth et al. for pure $\mathrm{TiO}_{2}$. Titanium isopropoxide mixed with distilled water and 2-Propanol was the other precursor solution.Finally white precipitate was formed. Efficiency of the solar cell was $68 \%$ [31]. 
Table 2. Sol-Gel Method

\begin{tabular}{|c|c|c|c|c|}
\hline S.No & $\mathrm{TiO}_{2}$ morphologhy & Particle size & Phase & Precursors \\
\hline 1 & Titanium alkoxides, $445^{\circ} \mathrm{C}, 2 \mathrm{hr}$ & $3.8-9.2 \mathrm{~nm}$ & Anatase & Halide precursorsers [32]. \\
\hline 2 & $\begin{array}{l}\text { Conventional sol-gel method, Titanium } \\
\text { isopropoxide, } 500^{\circ} \mathrm{C}, 30 \mathrm{mins}\end{array}$ & $1.5-20 \mathrm{~nm}$ & Anatase & $30 \mathrm{ml}$ isopropanal [33]. \\
\hline 3 & $\begin{array}{l}\text { Surfactant wrapping sol gel method, } \\
\text { Titaniumisopropoxide, } 35 \mathrm{mg} \text { acid } \\
\text { treated(raw), } 500^{\circ} \mathrm{C}, 30 \mathrm{mins}\end{array}$ & $0.88-35 \mathrm{~nm}$ & Anatase & $\begin{array}{l}0.5 \mathrm{wt} \% \text { sodium } \\
\text { dodecylbenzene sulfonate, } \\
20 \mathrm{ml} \text { ethonol [34]. }\end{array}$ \\
\hline 4 & $\begin{array}{l}\beta \text { - tricalcium and Hydraxapatite (from } \\
\text { animal bone) }\end{array}$ & 3-5 nm long & Anatase & $\begin{array}{l}\mathrm{NaCl} \text { and distilled water } \\
\text { [35]. }\end{array}$ \\
\hline 5 & $\mathrm{Cuo}^{-\mathrm{TiO}_{2}-\mathrm{XN}_{\mathrm{x}} \text { nanoparticles }}$ & $56.8 \mathrm{~nm}$ & Anatase & $\mathrm{CO}_{2}$ Conversion [35]. \\
\hline
\end{tabular}

Flow chart for solgel method

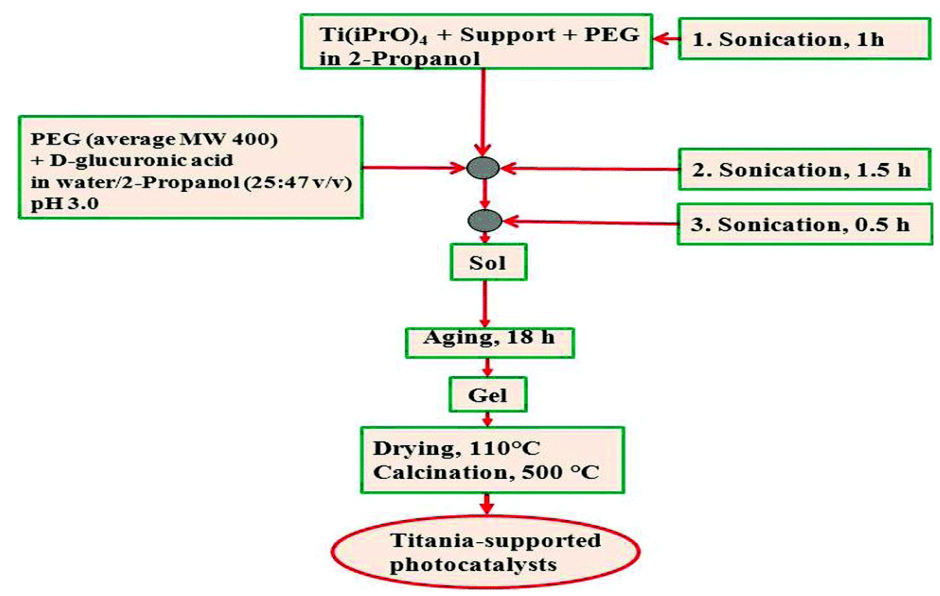

Figure 5. Flow Chart for Preparation of $\mathrm{TiO}_{2}$ Nanoparticles Using Sol-Gel Method

\section{HYDROTHERMAL/SOLVOTHERMAL METHOD}

This technique is an important tool for advanced nanostructured material processeing. Nanoparticles are prepared by steel pressure vessel called autoclave under controlled temperature can be elevated above the boiling point of the water/organisms. There are several hydrothermal methods are their conventional, ultrasonic assisted and microwave assisted. Kunyang Chen et al. explained that $1 \mathrm{~g}$ of $\mathrm{TiO}_{2}$ immersed in $\mathrm{NaOH}(50 \mathrm{ml}$ of $10 \mathrm{~mol} / \mathrm{L})$ hydrothermal related $180^{\circ} \mathrm{C}$ for $12 \mathrm{hr} .40 \mathrm{ml}$ of acid solution $\left(\mathrm{HNO}_{3}, \mathrm{H}_{2} \mathrm{SO}_{4}\right.$ or $\left.\mathrm{CH}_{3} \mathrm{COOH}\right)$. The concentrations of $\mathrm{HF}, \mathrm{HCl}$ and $\mathrm{HNO}_{3} 0.015-1.5 \mathrm{~mol} / \mathrm{L}$ [32].

$\mathrm{Na}-\mathrm{Titanate}+\mathrm{HF}$

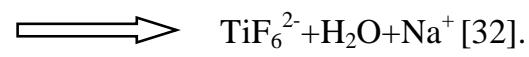

Another method to produce $2 \mathrm{~g}$ of $\mathrm{TiO}_{2}$ nanoparticles $+100 \mathrm{ml}$ of $\mathrm{NaOH}(10 \mathrm{~mol} / \mathrm{L})$. This mixture refluxed for $24 \mathrm{hrs} / 40^{\circ} \mathrm{C}$. After filtration white product treated with $0.1 \mathrm{~mol} / \mathrm{L}$ of HCL \& distilled water $(\mathrm{PH}$ level less than 7). Finally Nanoparticles was dried at room temperature and calcined at $300^{\circ} \mathrm{C}$ for 1hour.finally prepared nanotubes range between 300-800 $\mathrm{nm}$ in length and 15-30 nm in diameter [14]. 10-15 $\mathrm{NaOH} 16-72$ Teflon lines autoclave at $110-180^{\circ} \mathrm{C}$, the precipitate washed with deionized water and dispersed in $\mathrm{HCl}$. This method is used to preparing ceramic materials like $\mathrm{ZrO}_{2}, \mathrm{CeO}_{2}$ and $\mathrm{Fe}_{2} \mathrm{O}_{2}$ [33].

Table 3: Hydrothermal Method

\begin{tabular}{|c|c|c|}
\hline Auxiliary methods & $\begin{array}{l}\text { Conditions for } \\
\text { hydrothermal reaction }\end{array}$ & Dimensions of nanoparticles \\
\hline $\begin{array}{c}\text { Conventional } \\
\text { hydrothermal [35] }\end{array}$ & $\begin{array}{l}5 \mathrm{~g} \mathrm{TiO}_{2} \text { powder in } 10 \mathrm{M} \\
\text { sodium hydroxide } \\
(\mathrm{NaOH}), 50^{\circ} \mathrm{C} \text {, for } 20 \mathrm{~h}\end{array}$ & $\begin{array}{l}\text { Washing with } 0.1 \mathrm{M} \text { nitric acid }\left(\mathrm{HNO}_{3}\right) \text { Average }=9 \mathrm{~nm} \text {, } \\
\text { Average } \mathrm{Di}=6 \mathrm{~nm} \text {, Interlayer spacing }=0.7 \mathrm{~nm}(2-4 \text { walls }) \\
\quad \mathrm{L}=0.3-3.0 \mathrm{~nm} \text {, Specific surface area }=423 \mathrm{~m}^{2} / \mathrm{g} .\end{array}$ \\
\hline $\begin{array}{l}\text { Ultrasonication- } \\
\text { assisted hydrothermal } \\
\text { [33] }\end{array}$ & $\begin{array}{l}150 \mathrm{mg} \mathrm{\textrm {TiO } _ { 2 }} \text { powder in } \\
30 \mathrm{~mL} \text { of } 10 \mathrm{M} \mathrm{NaOH}\end{array}$ & $\begin{array}{c}\text { Mixture was sonicated at } 280 \mathrm{~W} \text { for } 60 \min 110 \circ \mathrm{C} \text { for } 4 \\
\text { h, Acid washing with } 0.1 \mathrm{M} \mathrm{HNO}_{3} \text {, Average } \mathrm{Do}=5 \\
\mathrm{~nm} \text {, Wall thickness }=1.3 \mathrm{~nm}, \mathrm{~L}=200-3 \mathrm{~nm} \text {. }\end{array}$ \\
\hline $\begin{array}{c}\text { Microwave-assisted } \\
\text { hydrothermal [32] }\end{array}$ & $\begin{array}{l}0.5 \mathrm{~g} \mathrm{TiO}_{2} \text { rutile in } 25 \mathrm{ml} \\
\text { of } 10 \mathrm{M} \mathrm{NaOH},\end{array}$ & $\begin{array}{l}\text { Acid washing with } 0.1 \mathrm{M} \mathrm{HNO}_{3}, \mathrm{Di}=3-5 \mathrm{~nm}, \mathrm{Do}=8-10 \\
\text { nm, L=100-500 nm. }\end{array}$ \\
\hline
\end{tabular}




\section{ELECTROCHEMICAL ANODIZATION}

Electrochemical anodization technique is a relatively simple, cheap and effective technique to fabricate highly ordered $\mathrm{TiO}_{2}$ nanotubes.

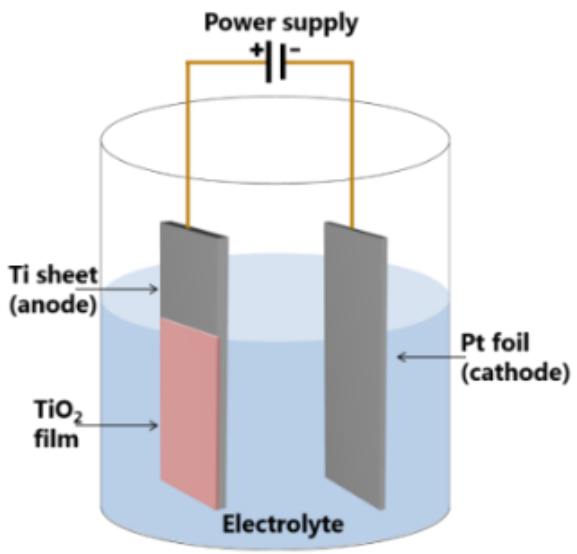

Figure 6. Electrochemical Anodization Technique

Titanium di oxide nanoparticles were first prepared by zwilling et al. in 1997 using chromic acid and hydrofluric acid. The potential difference between anode and cathode was 0 to 5.The specimen was treated in several voltages and different times between 0 to 55 mins. HF solution flurine plays an important role in antidote, oxidation and disolution process happens finally porous alumina growth happened [35].

The anodization process explained in step by step as follows: oxide barrier layer formed

$$
\begin{array}{lll}
\mathrm{Ti}^{4+}+2 \mathrm{H}_{2} \mathrm{O} & \longrightarrow & \mathrm{TiO}_{2}+4 \mathrm{H}^{+} \\
\mathrm{TiO}_{2}+6 \mathrm{~F}^{-}+4 \mathrm{H}^{+} & \longrightarrow & {\left[\mathrm{TiF}_{6}\right]^{2-}+2 \mathrm{H}_{2} \mathrm{O}}
\end{array}
$$

The growth of nanotubes is related to the diffusion of F-ions through the oxide layer and

\begin{tabular}{|c|c|c|c|}
\hline Anodization categories & $\begin{array}{l}\text { Types of } \\
\text { titanium } \\
\text { electrolytes }\end{array}$ & Conditions anodization & $\begin{array}{l}\text { Dimensions } \\
\text { of nanotubes }\end{array}$ \\
\hline $\begin{array}{c}\text { Hydrofluoric acid (HF) } \\
\text { based electrolytes (first } \\
\text { generation) [32]. }\end{array}$ & $\begin{array}{l}\text { (i) Titanium foil (thickness: } \\
\text { n.d.) (ii) } 0.5-3.5 \text { wt. } \% \mathrm{HF} \\
\text { aqueous solution }\end{array}$ & $\begin{array}{l}\text { Voltages: } 10-40 \mathrm{~V} \text { Duration: } 20 \mathrm{~min} \\
\text { to } 6 \mathrm{~h} \mathrm{D}=60 \mathrm{~nm} \mathrm{~L}=250 \mathrm{~nm},(\mathrm{i}) \\
\text { Titanium foil (thickness: } 0.2 \mathrm{~mm} \text { ) }\end{array}$ & $\begin{array}{c}\mathrm{D}=40-110 \\
\mathrm{~nm}, \mathrm{~L}=1 \mathrm{~m} \\
\mathrm{~S}_{\mathrm{s}}\end{array}$ \\
\hline $\begin{array}{l}\text { Water-based electrolyte } \\
\text { containing fluoride ion } \\
\text { (second generation) [33]. }\end{array}$ & $\begin{array}{l}\text { (i) } \begin{array}{c}\text { Titanium foil } \\
\text { (thickness: } 0.2 \mathrm{~mm} \text { ) }\end{array} \\
\text { (ii) } 3 \mathrm{wt} \% \text { of ammonium } \\
\text { fluoride }(\mathrm{NH} 4 \mathrm{~F}) \text { in } 1 \mathrm{M} \text { sodium } \\
\text { sulfate }(\mathrm{Na} 2 \mathrm{SO} 4) \text { solution }\end{array}$ & $\begin{array}{l}\text { Voltages: 20V Duration: } 30 \mathrm{~min} \text { to } 3 \mathrm{~h} \\
\mathrm{D}=90 \mathrm{~nm} \mathrm{~L}=0.7-2.5 \mathrm{~m} \text { Wall } \\
\text { thickness }=20 \mathrm{~nm} \text { (i) Titanium foil } \\
\text { (thickness: } 0.5 \mathrm{~mm} \text { ) (ii) } 0.5 \mathrm{wt} . \% \\
\text { sodium fluoride in } 1 \mathrm{M} \mathrm{Na} 2 \mathrm{SO} 4 \\
\text { Voltages: } 20 \mathrm{~V} \text { Duration: } 2 \mathrm{~h}\end{array}$ & $\begin{array}{l}\text { Pore } \\
\text { diameter } \\
=75 \mathrm{~nm}, \\
\text { Surface area } \\
=94 \mathrm{~cm} \text { on } \\
4 \mathrm{~cm} \text { sample }\end{array}$ \\
\hline
\end{tabular}
diffusion of $\left[\mathrm{TiF}_{6}\right]^{2}$.

Table 4. Electrochemical Anodization Technique

\section{CHARACTERISATION OF TITANIUM DIOXIDE NANOPARTICLES}

Morphological characterisation of $\mathrm{TiO}_{2}$ film by X-ray diffraction chromatography and scanning electron microscopy. Figure 6(a) shows the XRD pattern of sol-gel $\mathrm{TiO}_{2}$ nanoparticles at $450^{\circ} \mathrm{C}$, which indicates a mixture of the anatase and rutile phases. The XRD pattern of $\mathrm{TiO}_{2}$ nanoparticles shows prominent anatase peaks at (101), (004), (200) and prominent rutile peaks at (110) and (101). Figure 6(b) shows the XRD patterns of Titanium dioxide nanoparticle nanotubes (TNT) films prepared at hydrothermal temperature at $150^{\circ} \mathrm{C}$ for $12 \mathrm{~h}$. The $\mathrm{TiO}_{2}$ nanoparticles were observed to be transformed into the anatase phase by the 
hydrothermal method. As it can be observed from the corresponding XRD patterns [Figure 6(b)], the TNTs possess a highly crystallised anatase structure without any impurity phase. In the TNTs, the rutile peaks indicate that the transformation to anatase is complete.

FE-SEM images of the $\mathrm{TiO}_{2}$ sol-gel nanoparticles and the TNTs prepared at hydrothermal temperatures are shown in Figures 7(a) and 7(b). The diameter of the $\mathrm{TiO}_{2}$ nanoparticles prepared by the solgel method is consistently about $25 \mathrm{~nm}$. Figure 7(b) shows an FE-SEM image of the sample anatase TNTs which were grown at $150^{\circ} \mathrm{C}$ for $12 \mathrm{~h}$ and exhibit a pure tube-like structure. The length of the TNTs is several macrometers, their diameter is approximately 50 to $100 \mathrm{~nm}$, and they are very uniform, quite clean, and smooth-surfaced. A DSSC with a light-to-electric energy conversion efficiency of $4.56 \%$ was achieved under a simulated solar light irradiation of $100 \mathrm{~mW} / \mathrm{cm}^{2}$. The DSSC based on a $\mathrm{TiO}_{2} / \mathrm{TNT}$ combination at the optimal weight percentage (10 wt. \% TNT) showed better photovoltaic performance than the cell made purely of $\mathrm{TiO}_{2}$ nanoparticles [35].

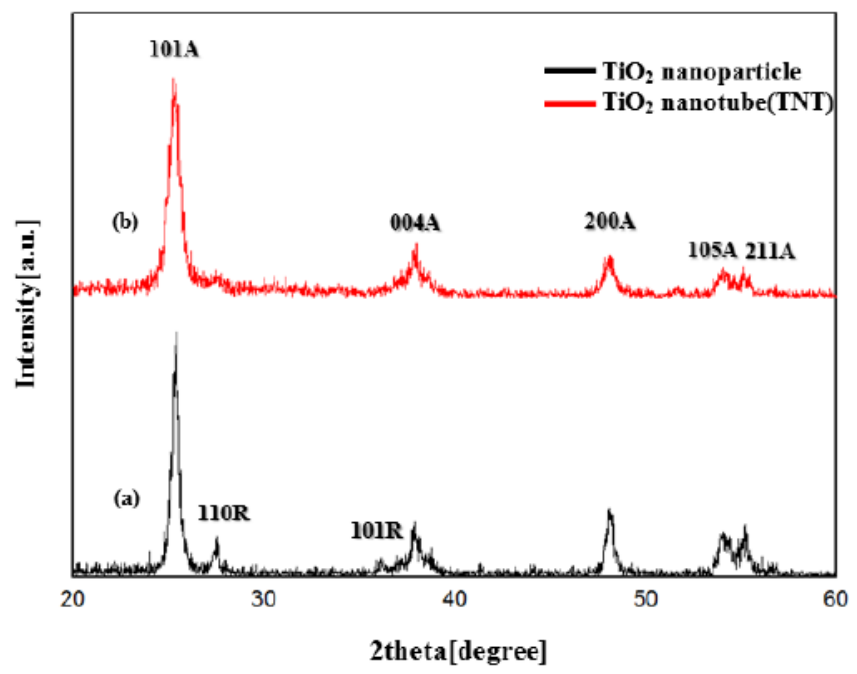

Figure 7. XRD Patterns of (a) $\mathrm{TiO}_{2}$ Nanotube (TNT) and (b) $\mathrm{TiO}_{2}$ Nanoparticles.
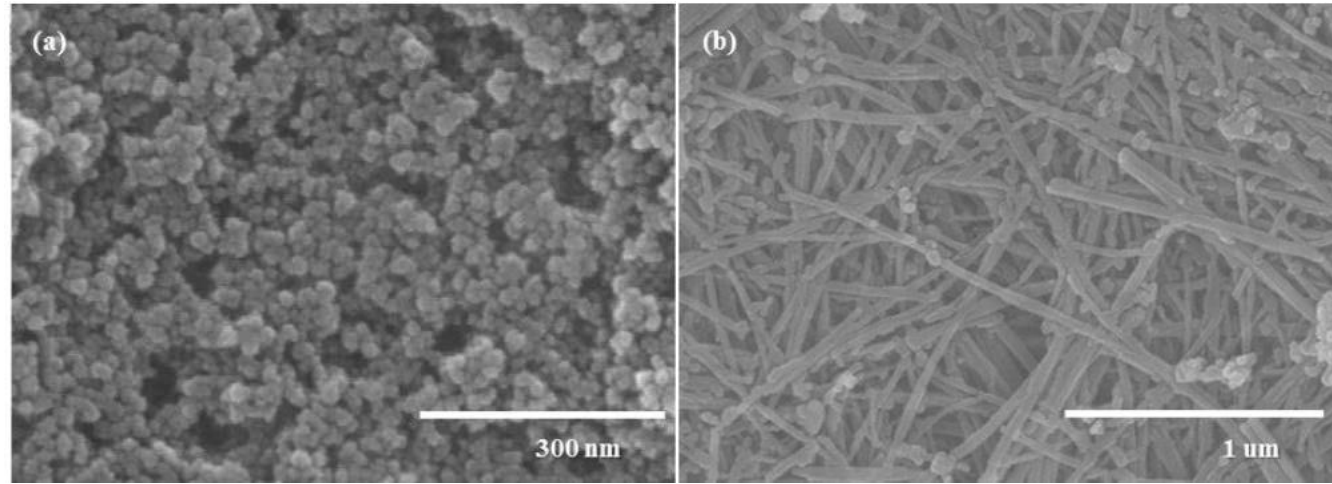

Figure 8. FE-SEM Images of $\mathrm{TiO}_{2}$ Nanoparticles and TNT Films, (a) $\mathrm{TiO}_{2}$ Nanoparticles Made by Sol-gel Method (b) TNT Films Made by Hydrothermal Method at $150^{\circ} \mathrm{C}$ for $12 \mathrm{~h}$

\section{CONCLUSION}

DSSCs are attractive because they are made up of cheap materials that do not need to be highly purified and can be printed at low cost DSSCs are unique compared with almost all other kinds of solar cells in that electron transport, light absorption and hole transport are each handled by different materials in the cell. Increasing the module efficiencies of DSSCs to more than $14 \%$ would relax the ultralow-cost constraints, thus providing substantial incentive to create laboratory-scale devices with efficiencies greater 
than $15 \%$. The relatively slow increase in record values for DSSCs over the past ten years left the impression of a performance ceiling, which is partially justified given that conventional iodide- and ruthenium-based and natural dye added DSSCs have a realistic maximum possible efficiency of little more than $13 \%$. The loss-inpotential can realistically be reduced to $500 \mathrm{mV}$ by better matching the energy levels at the heterojunction, using more strongly absorbing dyes in thinner films and further inhibiting recombination losses, pushing efficiencies to $19 \%$ with a dye capable of absorbing out to $920 \mathrm{~nm}$. Finally, although a number of initial studies into the development of DSSC modules, a thorough understanding of the overall lifetime degradation mechanism of new natural DSSC cell and module designs require a great deal of further investigation.

\section{REFERENCES}

[1] Fujishima, A.; Honda, K. "Electrochemical Photolysis of Water at a Semiconductor Electrode", Nature, vol .238, pp. $37-38$.

[2] Linsebigler, A. L.; Lu, G.; Yates, J. T. "Photocatalysis on TiO2 Surfaces: Principles, Mechanisms, and Selected Results", Chemical. Rev., vol. 95, pp 735-758, 1995.

[3] Jong Sung Park and Wonyong Choi, W. "Enhanced Remote Photocatalytic Oxidation on Surface-Fluorinated $\mathrm{TiO}_{2}$ Chem. Rev.,vol. 26, pp 11523-11527,2004.

[4] Thompson, T. L.; Yates, J. T., Jr. "Surface Science Studies of the Photoactivation of $\mathrm{TiO}_{2}$ - New Photochemical Processes", Chem. Rev. vol.10, pp 4428-4453,2006.

[5] Chen, X.; Mao, S. S. "Titanium Dioxide Nanomaterials: Synthesis, Properties, Modifications, and Applications,Chem. Rev.,vol. 107, pp 2891-959, 2007.

[6] Chen, H.; Nanayakkara, C. E.; Grassian, V. H. "Innovative three-dimensional (3D) eco- $\mathrm{TiO}_{2}$ photocatalysts for practical environmental and bio-medical applications", Chem. Rev.,vol. 112,pp 5919-5948, 2012.

[7] Zhang, Z.; Yates, J. T., Jr. "Band Bending in Semiconductors: Chemical and Physical Consequences at Surfaces and Interfaces", Chem. Rev. , vol.112, pp 5520-5551,2012.

[8] Henderson, M. A.; Lyubinetsky, I.” Molecular-Level Insights into Photocatalysis from Scanning Probe Microscopy Studies on TiO2(110)",Chem. Rev. 2013, vol.113, pp 4428-4455,2012.

[9] Pang, C. L.; Lindsay, R.; Thornton, G., "Structure of Clean and Adsorbate-Covered Single-Crystal Rutile TiO2Surfaces",Chem. Rev. 2013, 113, pp 3887-3948,2013.

[10] Aziz, A., Aziz, E.M., Zouggar, S., Aboutni, R., Tanouti, J. and Setti, M. (2013) 'Efficiency improvement of a photovoltaic system by acting on the characteristics of MPPT control', International Journal of Renewable Energy Technology, Vol. 4, No. 1, pp.44-64.

[11] Bandy, J., Zhang, Q. and Cao, G.," Electrophoretic Deposition of Titanium Oxide Nanoparticle Films for DyeSensitized Solar Cell Applications", Materials Sciences and Applications, vol.2, pp 1427-1431,2011.

[12] Dhungel, S.K. and Park, J.G. "Optimization of paste formulation for $\mathrm{TiO} 2$ nanoparticles with wide range of size distribution for its application in dye sensitized solar cells", Renewable Energy, Vol. 35, No. 12, pp.2776$2780,2010$.

[13] Gratzel M., J. "Dye-sensitized solar cells" Photochem. and Photobio C: Photochem Rev, vol. 2, pp.145-153, Jul. 2003

[14] Nazeeruddin Md. K., Baranoff E., Gratzel M.,’Dye Sensitized solar cells: A brief overview”, Sol. Energy, vol. 85, pp. 1172-1178, Mar. 2011.

[15] Habibi, M.H., Mikhak, M., Zendehdel, M. and Habibi, M. ,"Influence of nanostructured zinc titanate, zinc oxide or titanium dioxide thin film coated on fluorine doped tin oxide as working electrodes for dye-sensitized solar cell", International Journal of Electrochemical Science,Vol. 7, No. 8, pp.6787-6798 (2012).

[16] Haugan, J.A., Aakermann, T., Liaaen-Jensen, S.,'Isolation of fucoxanthin and peridinin. In: Enzymology, B.T.-M. (Ed.), Carotenoids Part A: Chemistry, Separation, Quantitation, and Antioxidation. Academic Press, vol 2,pp. 231-245,1998.

[17] Britton, G.,"General carotenoid methods. Methods Enzymol",Vol.111,pp 113-149,1985.

[18] Sandquist, C., McHale, J.L.,'Improved efficiency of betanin based dyesensitized solar cells”,J. Photochem. Photobiol. A Chem. Vol 221, pp 90-97.

[19] Robertson, N.,”Optimizing dyes for dye-sensitized solar cells “Angew. Chem.Int. Ed.vol 45 (15), pp 2338-2345, 2006.

[20] Anderson, S., Constable, E.C., Dare-Edwards, M.P., Goodenough, J.B., Hamnett, A., Seddon, K.R., Wright, R.D., "Chemical modification of a titanium (IV) oxide electrode to give stable dye sensitisation without a supersensitiser" Nature 280, 571-573, 1979.

[21] Luo, P., Niu, H., Zheng, G., Bai, X., Zhang, M., Wang, W., 2009. From salmon pink to blue natural sensitizers for solar cells: Canna indica L., "Salvia splendens, cowberry and Solanum nigrum "L. Spectrochim. Acta Part A Mol. Biomol. Spectrosc. 74, 936-942 2009.

[22] Kumar, K.A., Subalakshmi, K., Senthilselvan, J.,"Co-sensitization of natural dyes for improved efficiency in dyesensitized solar cell application”, AIP ,Conference Proceedings, vol. 1731, p. 060017,2016.

[23] Wu, J., Lan, Z., Hao, S., Li, P., Lin, J., Huang, M., Fang, L., Huang, Y.," Progress on the electrolytes for dyesensitized solar cells", Pure Appl. Chem.vol 80, pp 2241-2258, 2008.

[24] Chen, X. and Mao, S.S. "Titanium dioxide nanomaterials: synthesis, properties, modifications and applications", Chemical Reviews, Vol. 107, No. 7, pp.2891-2959, 2007. 
[25] El-Sayed, M.A.H. and Sharaf, A.M. (2011) "An efficient hybrid wave/photovoltaic scheme forenergy supply in remote areas", International Journal of Renewable Energy Technology, Vol. 2, No. 1, pp.67-85,2011.

[26] T Sekino - Inorganic and Metallic Nanotubular Materials,Springer,vol 1,16-22, 2010

[27] Poulomi Roy, Steffen Berger, and Patrik Schmuki, "TiO2 Nanotubes: Synthesis and Applications", nanoscience, reviews,pp 20159-60, (2012).

[28] L.L. Costa, A.G.S. Prado, J.,"TiO2 nanotubes as recyclable catalyst for efficient photocatalytic degradation of indigo carmine dye".Photochem. Photobiol. Vol. 201 ,pp 45-49,2009.

[29] H. Yu, J. Yu, B. Cheng, J. Lin, J. Hazard. Constructing a novel three-dimensional scaffold with mesoporous $\mathrm{TiO}_{2}$ nanotubes for potential bone tissue engineering Mater. 147 ,pp 581-587, 2007.

[30] Suguru Kubota,Kohei Johkumar,Kazuhiko Asanuma,Yasumitsu Okouchi,Naoko Ogiwara,Katsunori sasaki-Jornel , "Ultrastructural analysis of $\mathrm{TiO} 2$ nanotubes with photodecomposition of water into $\mathrm{O} 2$ and $\mathrm{H} 2$ implanted in the nude mouse”, Materials Science:Materials in Madicine ,vol 15 ,pp 1031-1035, 2004.

[31] Y. Zhu, H. Li, Y. Koltypin, Y.R. Hacohen, A. Gedanken, "Synthesis of $\mathrm{TiO}_{2}$ Nanowires via Hydrothermal Method", Chem. Commun. vol.55,pp 2616-2617.

[32] Yan Wang, Yiming He, Qinghua Lai, Maohong Fan, "High efficiency photocatalytic conversion of $\mathrm{CO}_{2}$ with $\mathrm{H}_{2} \mathrm{O}$ over Pt/TiO ${ }_{2}$ nanoparticles", Jornel of environmetal science, vol.4, pp 44442-44451, 2014.

[33] Chen Xiaobo-chinese, "Titanium Dioxide Nanomaterials and Their Energy" Applications journel of catalysis, vol 30, pp 839-851, 2009.

[34] Bin Gao,George Z.Chen,Gianluca Li Puma, "Carbon nanotubes/titanium dioxide $\left(\mathrm{CNTs} / \mathrm{TiO}_{2}\right)$ nanocomposites prepared by conventional and novel surfactant wrapping sol-gel methods exhibiting enhanced photocatalytic activity”,Applied catalysis B: Enviromental ,vol.89,pp 503-509, 2009.

[35] Kunyang Chen, lizhong Zhu, Kun Yang, "Acid-assisted hydrothermal synthesis of nanocrystalline $\mathrm{TiO}_{2}$ from titanate nanotubes: Influence of acids on the photodegradation of gaseous toluene", journel of environmental sciences, vol.27, pp 232-240, 2015.

[36] Lee, C.H., Rhee, S.W. and Choi, H.W. "Preparation of TiO2 nanotube/nanoparticle composite particles and their applications in dye-sensitized solar cells", Nanoscale Research Letters, Vol. 7,pp.48-55 (2012). 